Article

\title{
Willingness-to-Pay for Environmental Measures in Non-Profit Sport Clubs
}

\author{
Tim F. Thormann and Pamela Wicker *(D) \\ Department of Sports Science, Bielefeld University, Universitaetsstr. 25, 33615 Bielefeld, Germany; \\ tim.thormann@uni-bielefeld.de \\ * Correspondence: pamela.wicker@uni-bielefeld.de; Tel.: +49-521-106-12994
}

Citation: Thormann, T.F.; Wicker, P. Willingness-to-Pay for Environmental Measures in Non-Profit Sport Clubs. Sustainability 2021, 13, 2841. https://doi.org/10.3390/su13052841

Academic Editor:

Christopher Hautbois

Received: 2 February 2021

Accepted: 3 March 2021

Published: 5 March 2021

Publisher's Note: MDPI stays neutral with regard to jurisdictional claims in published maps and institutional affiliations.

Copyright: (C) 2021 by the authors. Licensee MDPI, Basel, Switzerland. This article is an open access article distributed under the terms and conditions of the Creative Commons Attribution (CC BY) license (https:// creativecommons.org/licenses/by/ $4.0 /)$.

\begin{abstract}
To reduce global warming and climate change, the German government plans to implement a carbon tax, which will also affect sport organizations. This study investigates how much sport club members are willing to pay for environmental measures and how sport-specific, club-specific, environmental, and socio-demographic factors are associated with their willingness-to-pay. In 2019 and 2020, active adult sport club members in five team/racket sports were sampled using an online survey in Germany $(n=3036)$. The contingent valuation method was applied to estimate sport club members' willingness-to-pay for environmental measures. Regression analyses were employed to investigate a set of factors that are associated with club members' decision to pay at all and the amount of willingness-to-pay. The results show that $64.3 \%$ of respondents reported a positive willingness-to-pay. The average willingness-to-pay for environmental measures amounts to EUR 14.53 per year and to EUR 22.59 for those reporting a positive willingness-to-pay. The results of $t$-tests show that club members stating a positive WTP differ significantly from members who are not willing to pay anything in terms of sport-specific, club-specific, environmental, and sociodemographic factors. The logistic regression results indicate that the likelihood of reporting a positive willingness-to-pay increases with increasing environmental consciousness, educational level, weekly practice hours, identification and satisfaction with the club, and subjective well-being, while age has a U-shaped effect. The results of a Tobit model show that the amount of willingness-to-pay is positively determined by environmental consciousness, educational level, and satisfaction with the club. The findings suggest that the majority of club members are willing to pay higher membership fees for the implementation of environmental measures in sport clubs. Increasing members' level of environmental consciousness through educational initiatives represents a way for sport policy and sport managers to help increase financial support for environmental measures among club members.
\end{abstract}

Keywords: community sport; contingent valuation method; environmental sustainability; monetary valuation

\section{Introduction}

Climate change threatens natural life on Earth and carbon emissions must be reduced to prevent irreversible damage to the natural environment [1]. Specifically, the Intergovernmental Panel on Climate Change (IPCC) has stressed that measures need to be taken to reduce global warming and keep the increase in temperature below $1.5^{\circ} \mathrm{C}$ to avoid further irreversible damage to the natural environment [2]. As a result of these developments, governments around the world have taken action and come up with regulations to protect the natural environment. One example is the German government, which has decided to introduce a carbon tax, meaning that every ton of carbon emissions is taxed, and organizations can buy out carbon emissions in the form of certificate trading [3].

The United Nations Framework Convention on Climate Change (UNFCCC) assigned the sport sector an important role to achieve climate goals of the Paris Climate Agreement [4]. Consequently, the relationship between sport and the natural environment has 
attracted growing interest among sport management researchers [5]. Scholars have stressed that the relationship between sport and the natural environment is bidirectional in nature, suggesting that sport influences the natural environment and vice versa [6]. On the one hand, the degradation of the natural environment and increased global warming through climate change danger the existence of different kinds of sport, especially winter sports $[7,8]$. On the other hand, the operation of all types of sport organizations and sport events yields various negative externalities which harm the environment [5].

Specifically, the sport industry creates environmental impact through hosting sport events and league competitions, provision of sport programs for active participants who need to travel to sport facilities and locations, and the operation of sport facilities [5,9]. Sport facilities include sport stadiums and sport halls which typically consume large amounts of energy and, hence, produce indirect carbon emissions $[5,10]$. This means that sport organizations using sport facilities are also affected by the introduction of carbon certificates and should, therefore, have a natural interest in reducing associated costs in the form of taxes. One way to reduce such environmentally harmful behavior and carbon costs is by implementing environmental measures, such as energy-saving installations, solar-energy, water-saving fountains, waste reduction, recycling of products, and reuse of resources. However, cost-saving benefits will not occur immediately, only in the long run, because acquisition costs are usually high $[5,11]$. These acquisition costs must be financed.

The research context of this study is non-profit sport clubs in Germany which offer team and/or racket sports, hence sports requiring sport facilities to be played. These sport clubs have different revenue sources, with revenues from membership fees representing the most important revenue category across clubs [12]. However, the overall level of membership fees is considered relatively low when compared to commercial sport providers, especially in team sports [13]. Hence, one way to finance environmental measures and potential acquisition costs is through increasing membership fees. Previous research has shown that club members are willing to pay higher membership fees contingent on the proposed use of the money, club members' personal situation, and the clubs' organizational capacity [14-16]. Environmental measures or aspects of the natural environment have not yet been included in previous research studying willingness-to-pay in non-profit sport clubs. However, increasing membership fees is a delicate topic in sport clubs, meaning that club management needs to know members' willingness-to-pay (WTP) to make informed decisions.

The purpose of the current study is to enhance our understanding of members' WTP for environmental measures and the factors that are associated with members' WTP. The investigation proposes two research questions: (1) what share of club members are willing to pay for environmental measures and if so, how much are they willing to pay in terms of higher membership fees? (2) What factors are associated with club members' WTP? The research questions will be answered using survey data of club members in five team/racket sports who completed an online survey. The findings will help to inform policy makers and club managers about the financial contribution club members are willing to make to improve the clubs' environmental quality and reduce the environmental impact of sport clubs.

\section{Theoretical Framework and Literature Review}

\subsection{Environmental Measures: Goods and Values}

Most environmental goods and services are non-market goods, meaning that they are not traded on a market and, therefore, have no prices [17]. Nonetheless, informed decisionmaking in several areas (e.g., policy, management) requires concrete numbers and monetary values. The concept of total economic value is employed to assign monetary values to such goods, which distinguishes between use and non-use values [18]. Use values can only be observed for environmental goods that can actually be consumed, i.e., the consumption of seafood or visitation of environmental landmarks by tourists. On the other hand, many benefits that the environment offers to individuals are associated with non-use values 
which are divided into existence, altruistic, and bequest [17]. The existence value emerges from the pure existence of a good such as the existence of a forest or marine ecosystem [18]. The altruistic value captures the knowledge and appreciation that a good or service is used by others, while the bequest value reflects the usage of a good by future generations, like passing enough environmental resources on to future generations [17].

In the present research context of sport clubs, further types of goods are relevant. Public goods are characterized by non-rivalry in consumption and non-excludability from consumption [19], with large parts of the natural environment (e.g., fresh air, clean water) meeting these characteristics as nobody can be excluded from its usage [20]. Most public goods qualify as non-market goods. Moreover, club goods are relevant, characterized by excludability from consumption (through a price) and non-rivalry in consumption, but only to the point of congestion $[20,21]$. Sport club memberships are considered club goods where members pay a general usage fee (membership fee) which provides them with a general usage right of the club programs and facilities [16].

The present study is at the intersection of public, non-market, and club goods. Environmental measures in sport clubs enhance the quality of the public good 'natural environment', while the payment vehicle to finance the public good has a club goods character (i.e., membership fee). The creation and conservation of public goods is typically challenging as individuals want to benefit from their usage, but do not want to pay for them (i.e., free-rider problem; [19]). Likewise, financing club goods might also cause free-rider problems [21], but to a lesser extent, given the social pressure of other club members and the agreement of club members to follow similar goals and pool resources [22]. Hence, the present research context and proposed payment vehicle might attenuate the free-rider problem. The non-market goods character of environmental measures is addressed by employing a valuation approach which puts a price tag on the intangible good.

\subsection{Contingent Valuation Method}

Different valuation approaches were developed to assign monetary values to nonmarket goods, acknowledging that decision-makers at the policy level require concrete numbers to legitimize spending decisions [17]. However, the need for evidence-based decision making has also increased in community sport [23], indicating the relevance of valuation approaches to the sport club context. Valuation approaches can be divided into revealed preference versus stated preferences approaches. Revealed preference approaches are based on data that assess individuals' behavior, assuming that individuals reveal their preferences through actual behavior [18]. In contrast, stated preference approaches rely on structured questionnaires to assess individuals' preferences. Importantly, many decisions require information about individuals' preferences ex ante, implying that data about actual behavior is typically not available. Given their hypothetical nature, stated preference approaches are highly flexible and can be adapted to the respective context and type of information required. The contingent valuation method (CVM) represents the most frequently employed stated preference approach in sport research $[17,24]$.

CVM is a survey-based method which includes a hypothetical scenario in the heart of the survey which creates a hypothetical market for a good. Respondents are asked to state how much they are willing to pay for a change in quantity or quality of the respective good [25]. A CVM scenario is characterized by different parameters that can be adjusted to the specific research context, including payment vehicle (e.g., tax, donation), payment period (e.g., lump sum payment, monthly payment for several years), and response format (e.g., open question, payment card, dichotomous choice; [17]). In this study, the membership fee serves as the payment vehicle which diminishes the free-rider problem [19]. Two different payment periods are used (five and ten years) and answers are provided in a payment card format where respondents are asked to indicate their likelihood of paying specific increases in membership fee. One major limitation of CVM is a potential hypothetical bias, as the hypothetical nature of the method can result in differences between 
stated WTP and actual WTP [26]. However, the literature has documented inconsistent findings for hypothetical bias and has suggested several ways to mitigate it [27].

\subsection{WTP in Sport and Environmental Research}

CVM was originally developed in environmental research where it gained popularity after assessing the monetary value of the natural resource damages resulting from the Exxon Valdez oil spill in 1989 [28]. Since then, CVM was applied to examine individuals' WTP for several environmental resources, including marine [29] and national park conservation [30], urban wetlands [31], coastline protection [32], urban green spaces [33], environmental quality improvement [34], and general environmental improvements [35]. Within Europe, Huhtala [36] estimated the WTP for national parks and state-owned recreation areas in Finland using CVM. About $68 \%$ of the population reported a positive WTP. Average WTP was estimated at 111 Finnish mark (FIM) per year which is equivalent to EUR 19. Using data from the European Values Survey, Ercolano et al. [35] studied the WTP to prevent environmental pollution measured by a four-point Likert scale variable. Male gender and educational level were positively related to WTP, while age was insignificant. In the Italian subsample, educational level also had a positive effect on WTP, while gender and income were insignificant [37]. In Germany, Witzke and Urfei [38] studied the WTP for environmental protection in terms of higher taxes. Income and education had a positive effect on the likelihood of WTP, while the age effect was u-shaped. Collectively, although all studies showed a positive WTP for environmental resources, some results suggest that the WTP for human benefits is still higher than for environmental benefits [39]. Additionally, many studies did not assess WTP in monetary terms, only on a Likert scale, hence providing only limited information about the actual amount of money individuals are willing to pay.

Within sport research, CVM and other valuation methods have been utilized in several contexts (for an overview see $[17,24]$ ). However, only a few studies have estimated the monetary value of environmental aspects in sport. Triantafyllidis and Kaplanidou [40] examined behavioral intentions of marathon runners related to donations for green initiatives. In another study, they investigated marathon runners' WTP for voluntary carbon offsetting [41]. In the context of professional team sports, Greenhalgh and Drayer [42] estimated fans' WTP for environmental initiatives. Huth and Kurscheidt [43] examined membership and green fees in German golf clubs and estimated the monetary value of an environmental certificate among golf club members using hedonic pricing. The WTP for environmental measures in community sport clubs has not yet been studied.

Only a few CVM studies have applied CVM in non-profit sport clubs to estimate members' WTP for increases in membership fees. Specifically, Kiefer [14] analyzed the WTP of riding club members in Germany for improvements in service quality. Other studies examined members' WTP and the potential to increase membership fees to meet increasing costs at the club $[15,16]$. These existing studies have not estimated the WTP for environmental measures, hence providing limited knowledge for club management in this area. Given the different types of goods involved and the natural environment representing a public good (rather than a club good), existing WTP findings for quality improvements in club goods can hardly be transferred to the question of environmental measures. Moreover, the above notion that WTP is typically higher for human benefits compared to environmental benefits [39] limits the applicability of existing findings in sport clubs. The present study attempts to address this research gap by connecting sport and environmental research and applying CVM in the sport club context to examine members' WTP for environmental measures and its determinants.

\subsection{Determinants of WTP}

Several factors are expected to determine club members' WTP for environmental measures, including members' environmental consciousness, educational background, income, and subjective well-being. Diekmann and Preisendörfer [44] conceptualized envi- 
ronmental consciousness as the attitudes individuals have towards the natural environment and the importance individuals attach to it. Following the theory of planned behavior, individuals' attitudes towards a specific behavior, subjective norms, and perceived behavioral control shape behavioral intentions [45]. Behavioral intentions do not only include intentions to perform different forms of pro-environmental behavior such as recycling behavior [46]. In fact, WTP as an expression of individuals' future financial behavior also qualifies as a behavioral intention in line with the concept of stated preferences, which represent behavioral intentions. Hence, according the theory of planned behavior [45], environmental consciousness will be positively associated with behavioral intentions and WTP, respectively.

Empirically, this positive relationship was confirmed in different settings, including purchasing environmentally friendly products [47] and visiting environmentally friendly lodging locations [48]. A positive relationship between environmental beliefs and proenvironmental intentions was also detected among spectators of collegiate athletics [49]. Moreover, environmental consciousness had a positive effect on individuals' intentions to donate for green initiatives [40] and their WTP for carbon offsetting [41]. The first hypothesis reflects the theoretical assumptions and the existing empirical evidence:

Hypothesis 1 (H1). Environmental consciousness is positively associated with members' WTP for environmental measures.

Second, educational background is positively correlated with environmental knowledge, with more time spent in educational institutions resulting in better environmental knowledge [50]. Environmental knowledge includes individuals' capability to identify symbols, concepts, and behavioral patterns related to environmental protection [51]. Empirical evidence mostly confirms that higher education increases environmental concerns [52] and environmental knowledge, resulting in higher pro-environmental intentions or behavior [53]. In environmental research, better educated people stated a higher WTP for the reduction in environmental risks [54], improvements in environmental quality [34], and general environmental measures [35]. Among sport club members, educational level was positively associated with WTP for membership fees [16]. These aspects are covered in the second hypothesis:

Hypothesis 2 (H2). Educational level is positively related to members' WTP for environmental measures.

Income typically affects individuals' WTP [24]. From an environmental research perspective, the luxury good hypothesis states that people with higher income can afford higher prices and are, therefore, more likely to purchase environmentally friendly products [55]. Put differently, one of the main reasons for not being willing to pay for environmental measures was spare income [30], supporting the luxury good hypothesis. Consequently, income is expected to have a positive influence on club members' WTP for environmental measures. This expectation is in line with empirical studies, documenting a positive association between income and WTP for environmental quality [34] and coastline protection [29]. The same relationship was found for WTP in non-profit sport clubs $[14,16]$. The third hypothesis reads as follows:

Hypothesis 3 (H3). Income is positively associated with members' WTP for environmental measures.

With subjective well-being becoming more important in recent public policy debates [56], the role of well-being in explaining individuals' economic behavior caught the attention of researchers (for a review see [57]), including sport scholars [58]. Expressing WTP for specific goods or services can be considered one form of economic behavior and economic behavioral intentions, respectively. Following theoretical discussions on 
the relationship between subjective well-being and economic behavior [57], well-being is negatively correlated with selfishness, meaning that happier people behave less selfishly. Selfishness is defined "as the prioritization of one's own material well-being over that of others" [57]. In the context of environmental measures, such behavior requires an individual to put the own needs behind the needs of the environment [57]. Previous research noted that when economic behavior is related to public goods, then happier individuals act more generously [59]. Since environmental improvements have a public goods character, it can be expected that happier individuals act less selfishly and are willing to pay more money to protect the natural environment. Several studies confirmed a positive relationship between well-being and pro-environmental behavior (e.g., [60,61]). Within sport, well-being was positively associated with individuals' WTP [58], but not in all studies (e.g., [62]). The fourth hypothesis reflects these aspects:

Hypothesis 4 (H4). Subjective well-being is positively related to members' WTP for environmental measures.

\section{Method}

\subsection{Sampling and Data}

A nationwide online survey among sport club members in Germany was conducted from June 2019 to March 2020. Data collection was terminated in March when community sport clubs were forced to stop their operations because of the COVID-19 pandemic. The respondents represent club members from five team and racket sports, including basketball, football, handball, ice hockey, and tennis. The platform www.soscisurvey.de was chosen to program the five sport-specific online surveys. Various online channels were used to distribute the link to active, adult sport club members, including social media, contact persons in clubs, and e-mails to sport club members which were sent out by club officials. Thus, a convenience and top-down snowball sampling was applied similar to previous research on individuals' WTP in sport clubs $[15,63]$.

In total, 3329 respondents finished the sport-specific surveys via the online platform. Since an undefined number of sport club members was reached by their club management, it was not possible to calculate a response rate. Altogether, 293 cases had to be deleted during the data cleaning process. While some cases were deleted due to providing same answers to every question which shows a lack of attention by the respondent, others failed plausibility and internal validity checks (e.g., activity years exceeded age). A final sample of $n=3036$ observations could be used for the empirical analysis.

\subsection{Questionnaire and Variables}

A standardized questionnaire was used which was adjusted to each sport. It opened with an introduction that gave respondents information about the voluntariness of participation and the anonymity of data. It consisted of different sections assessing club members' sport biography and club profile, WTP, environmental consciousness, well-being, and socio-demographic characteristics. Table 1 provides an overview of the variables. 
Table 1. Overview of variables $(n=3036)$.

\begin{tabular}{cc}
\hline Variable & Description \\
WTP & WTP for environmental measures in club (in EUR $)$ \\
WTP dummy & WTP higher than zero $(1=$ yes; $0=$ no $)$ \\
Payment period & Length of payment $(0=5$ years; $1=10$ years $)$ \\
Environmental & Environmental consciousness index $(1=$ not environmentally \\
consciousness & conscious; $5=$ highly environmentally conscious $)$ \\
Female & Respondent's gender $(1=$ female; $0=$ male $)$ \\
Age & Respondent's age (in years $)$ \\
Age squared & Age $\times$ Age \\
Low education & Highest educational level is below A-levels $(1=$ yes; $0=$ no $)$ \\
A-levels & Highest educational level is A-levels $(1=$ yes; $0=$ no $)$ \\
University & Highest educational level is university degree $(1=$ yes; $0=$ no $)$ \\
Income & Monthly personal net income (in EUR $)$ \\
Well-being & Well-being $(0=$ very low; $100=$ very high \\
Competitive athlete & Respondent competes in league competitions $(1=$ yes; $0=$ no $)$ \\
Practice hours & Weekly number of hours the sport is practiced \\
Activity years & Number of years the sport has been practiced \\
Membership fee & Current yearly membership fee (in EUR $)$ \\
Club identification & Identification with the sport club $(1=$ very low; $5=$ very high $)$ \\
Club satisfaction & Satisfaction with sport club $(1=$ very dissatisfied; $5=$ very \\
club environmental quality & satisfied $)$ \\
Basketball & Environmental quality of the club $(1=$ very poor; $5=$ very good $)$ \\
Football & Basketball $(1=$ yes; $0=$ no $)$ \\
Handball & Football $(1=$ yes; $0=$ no $)$ \\
Ice hockey & Handball $(1=$ yes; $0=$ no $)$ \\
Tennis & Ice hockey $(1=$ yes; $0=$ no $)$ \\
& Tennis $(1=$ yes; $0=$ no $)$ \\
\hline
\end{tabular}

The survey began with questions concerning the respondents' sport biography which included the number of years the sport has been practiced (Question: How many years have you played SPORT? Activity years) and the number of hours per week the sport is practiced (How many hours have you played SPORT on average per week in 2019/2020? Practice hours). The term SPORT was replaced by the respective type of sport in each survey (i.e., basketball, handball, etc.). The self-reported performance level was assessed with the following question: In which of the following performance categories do you classify yourself as a SPORT player? The following five categories were provided: leisure athlete (infrequent participation, no competitions), leisure athlete (frequent participation, no competitions), mass sport athlete (local competitions), performance athlete (regional competitions), and elite athlete (national and/or international competitions) [64]. In each sport-specific survey, the corresponding league levels for mass sport athletes, performance, and elite athletes were provided as a guidance for respondents. Since some performance levels contained only a small share of respondents (e.g., only $1.1 \%$ elite athletes), the performance level was divided into athletes with competitions at a local, regional, national, and international level and leisure/occasional sport athletes who do not compete at all. The resulting dummy variable (Competitive athlete) is 1 if the respondent is allocated to the former category and 0 for the latter.

In the club profile section, respondents were asked to state their identification (How much do you identify with your SPORT club? Club identification) and satisfaction with the club (How satisfied are you currently with the programs of your SPORT club? Club satisfaction) and their club's perceived environmental quality (How do you rate the environmental quality of your SPORT club overall? Club environmental quality). The level of the current membership fee (What yearly membership fee do you currently pay in your SPORT club? Membership fee) was also assessed because current financial obligations can influence members' WTP $[15,16]$.

The CVM scenario was at the heart of the survey and was preceded by the following information: 
To mitigate the increasing negative impacts of climate change, different options are available to reduce greenhouse gas emissions. As you might have heard from the news, politicians currently discuss the introduction of a carbon tax in Germany. This taxation would also affect sports in general and sport clubs, which would have to pay for the respective carbon emissions.

Afterwards, the following CVM scenario was provided to respondents:

Suppose your SPORT club wants to be more environmentally friendly to save costs in the long-term. Therefore, membership fees need to be increased to finance environmental measures that reduce emissions and protect the natural environment such as waste separation, energy saving lights by installing LED-lights, installing environmentally friendly buildings, renewable energies by installing solar panels, or reducing water consumption by installing new water-saving water fountains. Suppose every member has to contribute to financing these measures. How likely is it that you will pay the following amount in addition to your yearly membership fee over the next $X$ years?

For the payment period (denoted by $\mathrm{X}$ ), five or ten years (Payment period) were provided in randomized form to control for temporal embedding effects [65]. Overall, the presented scenario can be considered realistic because at the time of data collection, the carbon tax was discussed and also decided. A realistic scenario is important for the validity of CVM results [25]. Since the carbon tax was only decided during our sampling period, we could not include more concrete information about it in the scenario. Moreover, the wording of the scenario and the information provided had to be applicable to the team and racket sports included in the study. Moreover, sport clubs can be heterogeneous in terms of the specific infrastructure and facilities they provide. Hence, a more general wording was preferred to increase the applicability of the scenario to respondents' sport club and, consequently, the validity of the study [25]. Put differently, the idea was to avoid that respondents report no WTP simply because a specific scenario did not apply to their sport or club.

Individual's WTP was assessed using a payment card format where respondents were asked to indicate their likelihood of paying an increased membership fee. Different financial values were provided depending on the type of sport and the respective membership fee structure. The payment card was preferred over other answer options such as random selection formats as it reduces the possibility of hypothetical bias [27]. To further mitigate hypothetical bias, the payment card format was converted into a continuous variable by only considering those values where respondents clicked on $5=$ very likely [66]. The maximum amount for which a respondent stated 'very likely' represents his/her WTP (WTP). Put differently, if respondents did not reply 'very likely' for any amount, their WTP is 0 . Given the high number of zeros in WTP studies [17,24], a dummy variable is created reflecting whether respondents have a positive WTP $>0$ (WTP dummy).

Respondents' environmental consciousness was assessed using an existing scale (Table 2). The scale includes affective, conative, and cognitive items that capture the most important topics in the public debate of environmental protection in Germany [44]. A similar scale has been applied in previous sport environmental research [64,67]. Cronbach's alpha gives information about the construct reliability of a scale. It has a range from 0 to 1 , with higher values indicating higher reliability. Cronbach's alpha of the environmental consciousness scale is 0.842 suggesting strong construct reliability [68]. The calculated environmental consciousness index (Environmental consciousness) represents the mean value of the nine items. 
Table 2. Environmental consciousness scale.

Items (1 = Strongly Disagree; 5 = Strongly Agree)

Mean

SD

Please indicate how much you agree to the following statements.

$$
\text { Affective }
$$

1. It worries me when I think about the environmental circumstances under which our children and grandchildren have to live

2. When watching TV or reading newspaper article about environmental problems, I am often embarrassed and angry

3. If we continue our current style of living, we are approaching an environmental disaster

\section{Conative}

4. It is still true that politicians do not enough to protect the environment

5. In favor of the environment, we all should be willing to reduce our current standard of living

6. Environmental protection measures should also be enforced when jobs are lost as a result

\section{Cognitive}

7. There are limits of economic growth that our industrialized world has already passed or will reach soon

8. In my opinion, environmental problems are greatly exaggerated by proponents of the environmental movement (reverse coded) ${ }^{a}$

9. Science and technology will solve many environmental problems without us having to change our way of life (reverse coded) ${ }^{\text {a }}$

Note: ${ }^{\text {a }}$ Item recoded into $1=$ strongly agree to $5=$ strongly disagree; $\mathrm{SD}=$ standard deviation.

Members' subjective well-being was assessed using the World Health Organization's [69] well-being scale (short form: WHO-5; Table 3). Previous studies showed strong validity of the scale in different fields of research (e.g., [70]). The scale consists of five items with six possible answers (from $0=$ at no time to $5=$ all the time). The five items are added up and multiplied by 4, yielding a final well-being index (Well-being) between 0 and 100 . With a Cronbach's alpha of 0.824 , the scale can be considered reliable [68]. 
Table 3. WHO-5 scale.

\begin{tabular}{ccc}
\hline Items (0 $=$ at No Time; $\mathbf{5}=$ All of the Time) & Mean & SD \\
\hline Over the last two weeks ... & & \\
$\ldots$ I have felt cheerful and in good spirits & 4.46 & 0.99 \\
$\ldots$ I have felt calm and relaxed & 4.08 & 1.16 \\
$\ldots$ I have felt active and vigorous & 4.27 & 1.14 \\
$\ldots$ I woke up feeling fresh and rested & 3.60 & 1.31 \\
$\ldots$ My daily life has been filled with things that interests me & 4.11 & 1.13 \\
\hline Well-being (index; range 0-100) & 62.11 & 17.66 \\
\hline Cronbach's $\alpha$ & 0.824 & \\
\hline
\end{tabular}

Note: $\mathrm{SD}=$ standard deviation.

The survey finished with multiple questions assessing club members' socio-demographic characteristics similar to previous studies [14,42]. Respondents were asked to indicate their gender (What is your gender? Female), age (How old are you? Age), highest level of education (What is your highest educational level? Low education; A-Levels; University), and net income per month (What is your personal monthly net income? Income). The squared term of age (Age squared) was also calculated and included in the study, because the relationship between age and pro-environmental intentions in the form of WTP might be non-linear [71].

\subsection{Statistical Analysis}

The empirical analysis was two-fold and consisted of descriptive statistics and $t$-tests followed by a set of regression analyses. First, the descriptive statistics provide an overview of the sample structure and the WTP for environmental measures across sports. Moreover, independent samples $t$-tests are run to examine differences in sport-specific, club-specific, environmental, and socio-demographic factors between club members with and without a WTP higher than zero.

Second, three regression models were estimated. The regression models take two econometric issues into account. The first issue is the high proportion of zeros (35.7\%). This issue is common in CVM studies and is typically addressed by estimating a first model which examines the extensive margin, meaning whether respondents are willing to pay anything or not, and a second model analyzing the intensive margin, i.e., the determinants of the amount of WTP of those with a positive WTP (e.g., [63,66]). Accordingly, the first model is a logistic regression with WTP dummy as dependent variable to examine the factors associated with members' decision to pay any increase in membership fee for environmental measures. In the second model, the dependent variable is WTP, which is entered in logged form. This log-transformation addresses the skewed distribution of WTP and is common in CVM research [66]. The second model is based on a smaller number of observations as it excludes respondents with a WTP of zero. Hence, this first set of models acknowledges that WTP statements are two-part decisions [66,72]: First, respondents decide whether they are willing to pay anything or not and, second, in the case they are willing to pay anything, they decide the amount of money they are willing to pay.

The second issue is that the data are censored given the use of payment cards for the assessment of WTP. Hence, WTP is bound between 0 and the highest value of the payment card. To address this issue, the third model is a Tobit model which is adequate for censored data [73]. Tobit models have been employed in previous sport CVM research (e.g., [74-76]) and environmental CVM research (e.g., [36]).

The remaining variables from Table 1 were included as independent variables in all models. The models are based on the following general equation (below is the exemplary equation for the Tobit model): 
$\mathrm{WTP}=\beta_{0}+\beta_{1}$ Payment period $+\beta_{2}$ Environmental consciousness $+\beta_{3}$ Female +

$\beta_{4}$ Age $+\beta_{5}$ Age squared $+\beta_{6}$ A-levels $+\beta_{7}$ University $+\beta_{8}$ LN Income +

$\beta_{9}$ Well-being $+\beta_{10}$ Competitive athlete $+\beta_{11}$ Practice hours $+\beta_{12}$ Activity years +

$\beta_{13}$ Membership fee $+\beta_{14}$ Club identification $+\beta_{15}$ Club satisfaction +

$\beta_{16}$ Club environmental quality $+\beta_{17}$ Basketball $+\beta_{18}$ Handball $+\beta_{19}$ Ice hockey +

$\beta_{20}$ Tennis

Multicollinearity was checked for the independent variables: Except of age and age squared, the thresholds of 0.8 for the correlation coefficient and 10 for variance inflation factors were not exceeded, suggesting that multicollinearity should not be an issue in this study [68]. Similar to WTP, the natural logarithm of net personal income was built, because the income variable was positively skewed. Both regression models also control for the type of sport and were calculated with heteroscedasticity-consistent standard errors.

\section{Results}

The descriptive statistics (Table 4) show that respondents are, on average, 32.18 years old. The share of females is $32.6 \%$. Regarding educational level, $37.1 \%$ of respondents have a university degree, $40.5 \%$ stated A-levels as highest degree, and $22.3 \%$ have an education level below A-levels. On average, respondents practiced their sport for five hours a week. They have played their sport for 18.6 years. Concerning performance level, $58.1 \%$ of respondents participate regularly in league competitions. The three club characteristics were rated as follows: Average identification with the club was 4.06, satisfaction was 3.82, and the perceived environmental quality, was 3.38. Average well-being is 62.11 on a scale from 0 to 100 .

Table 4. Descriptive statistics and results of the $t$-tests.

\begin{tabular}{cccccc}
\hline & \multicolumn{2}{c}{ Full Sample } & $\begin{array}{c}\text { WTP } \\
\text { Dummy }=\mathbf{0}\end{array}$ & $\begin{array}{c}\text { WTP } \\
\text { Dummy }=\mathbf{1}\end{array}$ \\
\cline { 2 - 6 } Variable & Mean & SD & Mean & Mean & t \\
\hline WTP & 14.53 & 19.05 & 0 & 22.59 & - \\
WTP dummy & 0.643 & - & 0 & 1 & - \\
WTP basketball & 12.64 & 14.61 & 0 & 21.28 & - \\
WTP football & 10.69 & 12.16 & 0 & 15.84 & - \\
WTP handball & 8.29 & 8.02 & 0 & 11.65 & - \\
WTP ice hockey & 18.86 & 23.93 & 0 & 28.78 & - \\
WTP tennis & 21.69 & 26.31 & 0 & 36.03 & - \\
Payment period & 0.488 & - & 0.487 & 0.489 & -0.115 \\
Environmental & 3.72 & 0.71 & 3.47 & 3.86 & $-15.136^{* * *}$ \\
consciousness & 0.326 & - & 0.289 & 0.347 & $-3.285^{* * *}$ \\
Female & 32.18 & 14.61 & 33.77 & 31.30 & $4.476^{* * *}$ \\
Age & 1248.88 & 1246.25 & 1381.10 & 1175.53 & $4.369^{* * *}$ \\
Age squared & 0.223 & - & 0.270 & 0.198 & $4.591^{* * *}$ \\
Low education & 0.405 & - & 0.402 & 0.407 & -0.245 \\
A-levels & 0.371 & - & .0327 & 0.395 & $-3.702^{* * *}$ \\
University & 1816.82 & 1263.25 & 1868.08 & 1788.38 & $1.666^{*}$ \\
Income & 62.11 & 17.66 & 61.10 & 62.67 & $-2.340^{* *}$ \\
Well-being & 0.581 & - & 0.595 & 0.574 & 1.141 \\
Competitive & 4.98 & 3.12 & 5.12 & 4.91 & $1.846^{*}$ \\
athlete & 18.63 & 11.01 & 19.62 & 18.08 & $3.683^{* * *}$ \\
Practice hours & 136.57 & 122.40 & 138.47 & 135.52 & 0.637 \\
Activity years & 4.06 & 0.98 & 4.02 & 4.09 & $-2.057^{* *}$ \\
Membership fee & & & &
\end{tabular}


Table 4. Cont.

\begin{tabular}{cccccc}
\hline & \multicolumn{2}{c}{ Full Sample } & $\begin{array}{c}\text { WTP } \\
\text { Dummy }=\mathbf{0}\end{array}$ & $\begin{array}{c}\text { WTP } \\
\text { Dummy }=\mathbf{1}\end{array}$ \\
\cline { 2 - 6 } Variable & Mean & SD & Mean & Mean & t \\
\hline Club satisfaction & 3.82 & 0.94 & 3.74 & 3.87 & $-3.661^{* * *}$ \\
Club environmental & 3.38 & 0.86 & 3.42 & 3.36 & $1.748^{*}$ \\
quality & 0.208 & - & 0.237 & 0.192 & $2.907^{* * *}$ \\
Basketball & 0.289 & - & 0.263 & 0.303 & $-2.335^{* *}$ \\
Football & 0.124 & - & 0.101 & 0.138 & $-2.972^{* * *}$ \\
Handball & 0.153 & - & 0.148 & 0.156 & -0.585 \\
Ice hockey & 0.226 & - & 0.252 & 0.211 & $2.559 * *$ \\
Tennis & & - & & & \\
\hline
\end{tabular}

Note: ${ }^{*} p<0.1 ;{ }^{* *} p<0.05 ;{ }^{* *} p<0.01 ; \mathrm{SD}=$ standard deviation.

Currently, respondents pay an average yearly membership fee of EUR 136.57. Altogether, $64.3 \%$ of respondents are willing-to-pay for environmental measures in their sport club. The resulting average WTP amounts to EUR 14.53 per year (including zeros). Members of tennis and ice hockey clubs show the highest WTP with EUR 21.69 and EUR 18.86 per year, respectively. Yearly WTP is lower for basketball (EUR 12.64), football (EUR 10.69), and handball club members (EUR 8.29).

Table 4 also reports the differences between club members without and with positive WTP (i.e., higher than zero). The results of $t$-tests show that members with a positive WTP have a significantly higher level of environmental consciousness, they are more satisfied with the club, and identify more with the club, but perceive the club's environmental quality as lower than members with zero WTP. Females are better represented among members with positive WTP and their average age is slightly younger. Individuals with low educational levels (below A-levels) are less represented among members with positive WTP, while individuals with a university degree are significantly better represented. Those with positive WTP have lower income, lower weekly practice hours and fewer activity years, but higher well-being.

Table 5 summarizes the results of the regression models. While the logistic model explains $8.4 \%$ of the variance in positive WTP for environmental measures, the linear regression explains $31.4 \%$ of the variation in the amount of WTP of those respondents who are willing to pay anything. The Tobit model explains $2.1 \%$ of the variation in WTP.

Table 5. Regression models for willingness-to-pay (WTP).

\begin{tabular}{cccc}
\hline & $\begin{array}{c}\text { Model 1 (Logit): } \\
\text { WTP Dummy }\end{array}$ & $\begin{array}{c}\text { Model 2 (Linear): } \\
\text { LN WTP }\end{array}$ & $\begin{array}{c}\text { Model 3 (Tobit): } \\
\text { WTP }\end{array}$ \\
\hline Constant & - & $1.685^{* * *}$ & $-49.040^{* * *}$ \\
Payment period & 0.043 & $0.073^{* *}$ & 0.743 \\
Environmental & $0.172^{* * *}$ & $0.162^{* * *}$ & $10.969 * * *$ \\
consciousness & $0.010^{* *}$ & $-0.143^{* * *}$ & -1.71 \\
Female & $-0.009^{* *}$ & 0.005 & -0.309 \\
Age & $0.000^{*}$ & -0.000 & 0.002 \\
Age squared & Ref. & Ref. & Ref. \\
Low education & $0.053^{* *}$ & 0.064 & $4.297 * * *$ \\
A-levels & $0.115^{* * *}$ & $0.087^{* *}$ & $7.258^{* * *}$ \\
University & 0.010 & $0.008^{* *}$ & 0.788 \\
LN Income & $0.001^{*}$ & 0.000 & 0.044 \\
Well-being & -0.012 & $-0.084^{* * *}$ & -1.677 \\
Competitive athlete & $-0.005^{*}$ & 0.004 & -0.156 \\
Practice hours & -0.001 & $0.005^{* * *}$ & 0.050 \\
Activity years & 0.000 & 0.000 & 0.006 \\
Membership fee & & &
\end{tabular}


Table 5. Cont.

\begin{tabular}{cccc}
\hline & $\begin{array}{c}\text { Model 1 (Logit): } \\
\text { WTP Dummy }\end{array}$ & $\begin{array}{c}\text { Model 2 (Linear): } \\
\text { LN WTP }\end{array}$ & $\begin{array}{c}\text { Model 3 (Tobit): } \\
\text { WTP }\end{array}$ \\
\hline Club identification & $0.023^{* *}$ & $-0.030^{*}$ & 0.434 \\
Club satisfaction & $0.034^{* *}$ & 0.020 & $2.187^{* * *}$ \\
Club environmental & -0.012 & -0.011 & -0.931 \\
quality & $-0.120^{* * *}$ & $0.332^{* * *}$ & -1.621 \\
Basketball & Ref. & Ref. $^{* * *}$ & Ref. \\
Football & $0.052^{*}$ & $-0.184^{* * *}$ & $-0.132^{* *}$ \\
Handball & 0.016 & $0.497^{* * *}$ & $10.160^{* * *}$ \\
Ice hockey & -0.013 & $0.789^{* * *}$ & $12.711^{* * *}$ \\
Tennis & 3036 & 1952 & 3036 \\
\hline$n$ & 0.084 & 0.314 & 0.021 \\
Nagelkerke $R^{2} / R^{2}$ & $277.27^{* * *}$ & $48.89^{* * *}$ & $19.53^{* * *}$ \\
$\chi^{2} / F$ & $0 y+2 *$ the &
\end{tabular}

Note: ${ }^{*} p<0.1 ;{ }^{* *} p<0.05 ;{ }^{* * *} p<0.01$; displayed are the average marginal effects (logit) and unstandardized coefficients (linear and Tobit); Ref. = reference category; all models estimated with robust standard errors.

Environmental consciousness has a significant positive relationship with the outcome variable in all models: The higher the environmental consciousness, the more likely respondents are willing to pay for environmental measures and the higher the amount of WTP. Consequently, the first hypothesis can be confirmed.

Similar effects can be observed for effects of respondents' educational level. Respondents with A-levels or some kind of university degree are more likely to report a positive WTP for environmental measures. Similarly, respondents with a university degree have a significantly higher WTP than those with an educational level below A-levels. The effect of A-levels is also positive, but insignificant in Model 2. Both educational level variables have a significant positive effect on WTP in Model 3. Hence, the second hypothesis can be largely supported.

Income is insignificant in all models, meaning that the third hypothesis must be rejected. Sport club members' subjective well-being significantly and positively affects the WTP dummy, but not the amount of WTP. The well-being effect is insignificant in the loglinear (Model 2) and the Tobit model (Model 3). Therefore, the fourth hypothesis can only be confirmed for positive WTP.

Turning to control variables, age has a u-shaped effect on the WTP dummy, meaning that younger and older members have a higher likelihood to pay than middle-aged members. The likelihood of reporting a positive WTP also increases with increasing weekly practice hours as well as identification and satisfaction with the club.

In Model 2 considering only respondents with a WTP $>0$, the amount of WTP increases with a longer payment period and members' activity years, while competitive athletes, and those highly identifying with the club have a significantly lower WTP. Female members have a significantly lower WTP than their male counterparts.

In Model 3, satisfaction with the club is significantly and positively associated with WTP. The current membership fee level is insignificant in all models, indicating that it is not associated with the likelihood of reporting a positive WTP or the amount of WTP.

\section{Discussion}

The purpose of this study was to examine sport club members' WTP for environmental measures and a set of factors that are associated with WTP. The sample which was gathered through a nationwide online survey is larger than in previous studies that investigated proenvironmental intentions in sport [49]. Males, younger individuals, and highly educated people are better represented in the sample. This structure reflects the characteristics of members in German sport clubs (e.g., $[15,63])$. These sample characteristics are also typical in sport and environmental research $[33,64]$. 
The average WTP for environmental measures is lower than WTP of sport club members for other purposes in previous studies (e.g., $[14,16,63])$, but close to the amount what sport fans of professional teams are willing to pay for environmental sustainability initiatives [42]. The level of WTP is also similar to existing environmental research within Europe [36]. Differences in WTP compared to existing studies can be explained by the type of good outlined in the CVM scenario (i.e., increased service quality or training by a specific coach vs. environmental measures). Hence, the findings also echo existing environmental research in the sense that the WTP for human benefits is larger than for environmental benefits [39]. Moreover, differences in WTP can result from differences in response formats (open question vs. double dichotomous choice vs. payment card; [63]). On the contrary, different payment vehicles (i.e., extra fee in addition to ticket price in [42] vs. membership fee) did not yield material differences in WTP for similar goods which are both related to protecting the natural environment. Overall, respondents were willing to pay an additional amount of money that is equivalent to $10.6 \%$ of their current membership fee.

However, about one third of the surveyed members did not want to pay anything for environmental measures in their club. Such a high share of zeros is common in CVM sport research [17] and environmental research [36]. They could either reflect that respondents do not value the good of interest or that they do value it, but do not want to contribute to financing it. The latter case would represent a free-rider problem as these individuals would still benefit from the provision of the good and would be able to use it given the club goods character of the membership. The first regression model suggests that both explanations might apply: On the one hand, the positive effect of practice hours suggests that those utilizing the club good to a lesser extent also have a lower likelihood of a positive WTP, indicating that they feel that more frequent users should pay for the good [15]. On the other hand, members who score low on environmental consciousness might not value the good and, hence, state no WTP.

This positive effect of environmental consciousness on WTP in both models supports the main tenets of the theory of planned behavior in the sense that attitudes towards the natural environment predict behavioral intentions [45], which are captured by WTP in this study. The effect is also in line with findings from environmental research [47,48], research among college sport spectators [49], and sport environmental research on financing other environmental measures [40,41].

Likewise, environmental theory proposed that higher education leads to more environmental knowledge which, in turn, results in better pro-environmental intentions [50]. The present results suggest that these theoretical tenets can be transferred to WTP for environmental measures in sport clubs as the educational dummies were mostly positive and significant in both models. This positive relationship between educational level and WTP for environmental measures confirms existing research in various sport settings $[15,53]$ and in previous environmental research (e.g., $[35,37,38])$.

The insignificance of income indicates that the luxury good hypothesis, stating that higher income individuals have more financial resources to forgo some income for environmental measures [55], does not apply to this context. While income is a typical predictor of WTP in existing sport CVM studies [24], it was also not significant in previous sport club research [15]. One reason for this finding might be the overall low income level of the sample compared to the average income of the German population [77]. Another explanation is that the average membership fee is around $25 \%$ higher compared to previous research, suggesting that the costs for an extra payment increase with higher existing payments (e.g., $[14,15])$. Collectively, these circumstances might make extra payments difficult.

The positive effect of subjective well-being on club members' likelihood of reporting a positive WTP supports scholarly assumptions that higher well-being is positively associated with economic behavior [57]. Bearing in mind that the natural environment represents a public good and that happier people showed less selfishness related to public goods (e.g., [59]), a lower level of selfishness represents the mechanism through which well-being affects WTP. Put differently, happier people behave more generously which is 
reflected in their WTP. The positive association is in line with some existing studies [58], but not all [62]. The insignificant effect in the second model supports the notion that happier people are less generous (e.g., [78]). While the latter might be an explanation, many CVM studies share the phenomenon that the significances and directions of effect differ between the model for positive WTP and the amount of WTP model (e.g., [79]). This finding was interpreted in a way that respondents generally value the good, but do not want to give their money through the proposed payment vehicle. Similar to residents ${ }^{\prime}$ aversion to paying more taxes [79], club members might dislike paying higher membership fees [16].

The findings yield implications for policy makers and sport club managers. The German sport club system encompasses 24 million memberships [80]. Extrapolating this number with the average WTP yields an aggregate consumer surplus of about EUR 350 million per year for environmental measures. In light of this figure and the two thirds of club members indicating their willingness to contribute to financing acquisition costs, club managers and policy makers should be proactive in implementing environmental measures in club houses and sport facilities. Since individuals' level of environmental consciousness increases the acceptance of such extra payments, a number of initiatives should be planned that increase club members' environmental consciousness. For example, environmental education sessions can be integrated in team and members' meetings. Environmental workshops for club members could be offered that educate individuals about the environmental impacts of sport clubs. Additionally, environmental knowledge can be provided in other ways (e.g., signage in sport facilities and club houses). These initiatives will help enhance members' level of environmental knowledge and environmental consciousness, ultimately resulting in pro-environmental behavioral intentions. They might be especially fruitful for members with lower educational levels, as these individuals might not be able to overlook the long-term environmental consequences of their behavior.

\section{Conclusions}

This study examined sport club members' willingness to finance environmental measures in German sport clubs through increases in membership fees. It acknowledges that climate change is not only associated with threats to natural life, but also with increasing financial burdens for sport organizations when environmental measures are implemented. The legislation of the German government with respect to a carbon tax from 2021 onwards indicates that sport organizations face a pressing need to reduce their carbon emissions and, hence, the prices for carbon certificates. Such reductions can be achieved by investing in environmental measures which pay off in the long-term, but come with high acquisition costs that must be paid for by sport clubs and their members. Therefore, it is important to understand club members' WTP for such measures.

The present study found that $64.3 \%$ of respondents reported a positive WTP, meaning that they were willing to pay any amount higher than zero. Average WTP of these respondents is EUR 22.59 and EUR 14.53 of all respondents. Club members stating a positive WTP differ significantly from members who are not willing to pay anything in terms of sport-specific, club-specific, environmental, and socio-demographic factors. The likelihood of reporting a positive WTP (logit model) increases with increasing environmental consciousness, educational level, well-being, identification and satisfaction with the club, while it decreases with increasing weekly practice hours. The age effect suggested that middle-aged members have a higher likelihood of stating a positive WTP than younger and older members. The overall amount of WTP (Tobit model) increases with increasing environmental consciousness, educational level, and satisfaction with the club.

This work contributes to the body of CVM and sport ecology research in several ways. It is the first study that applies CVM to environmental initiatives in the context of sport clubs. Previous research employing CVM in sport clubs had other payment purposes. Hence, this research extends the applicability of CVM in sport to environmental measures. Moreover, it contributes to the body of sport ecology research by estimating 
individuals' willingness to contribute financially to environmental initiatives. In doing so, the study also contributes to environmental research where many studies have assessed WTP with categorical statements rather than monetary values. However, monetary values provide more concrete knowledge for policy and decision-making. Another contribution is the integration of subjective well-being in the WTP equation-both theoretically and empirically. This concept has been largely neglected in previous sport CVM research, but has gained attention in the economic behavior literature. While the relationship between subjective well-being and pro-environmental behavior has been investigated in the environmental literature before, this study extends the application to the sport club context.

This study comes with some limitations from which future research can evolve. First, future research could use variations from the 'CVM toolbox', including different scenarios, payment vehicles, response formats, and payment periods to enhance our understanding of the circumstances and conditions under which members are willing to pay for environmental measures in sport clubs. Second, the research context was limited to five team/racket sports and sport clubs in one European country. It would be interesting to extend the present research design to individual sports and other countries to identify differences between sports and countries.

Author Contributions: Conceptualization, P.W. and T.F.T.; methodology, T.F.T. and P.W.; formal analysis, T.F.T.; investigation, P.W. and T.F.T.; writing—original draft preparation, T.F.T.; writingreview and editing, P.W.; supervision, P.W.; project administration, P.W.; All authors have read and agreed to the published version of the manuscript.

Funding: This research received no external funding.

Institutional Review Board Statement: The study was conducted according to the guidelines of the Declaration of Helsinki. Approval by an Institutional Review Board was not necessary.

Informed Consent Statement: Not applicable.

Data Availability Statement: The data presented in this study are available on request from the corresponding author. The data are not publicly available due to data privacy reasons.

Acknowledgments: The authors would like to thank the following students who assisted with the data collection and initial data cleaning: Jannis Becker, Niklas Hunold, Marten Neppert, Felix Pföhler, Florian Pompino, and Simon Zimmermann.

Conflicts of Interest: The authors declare no conflict of interest.

\section{References}

1. Thomas, C.D.; Cameron, A.; Green, R.E.; Bakkenes, M.; Beaumont, L.J; Collingham, Y.C.; Hughes, L. Extinction risk from climate change. Nature 2004, 427, 145-148. [CrossRef] [PubMed]

2. IPCC. Global Warming of $1.5^{\circ} \mathrm{C}$. 2018. Available online: https://report.ipcc.ch/sr15/pdf/sr15_spm_final.pdf (accessed on 26 January 2021).

3. German Government. Klimaschutzprogramm 2030 [Climate protection program 2030]. Available online: https://www. bundesregierung.de/breg-de/themen/klimaschutz/klimaschutzprogramm-2030-1673578 (accessed on 25 January 2021).

4. Trendafilova, S.; McCullough, B.P. Environmental sustainability scholarship and the efforts of the sport sector: A rapid review of literature. Cogent Soc. Sci. 2018, 4, 1-15. [CrossRef]

5. McCullough, B.P.; Orr, M.; Watanabe, N.M. Measuring externalities: The imperative next step to sustainability assessment in sport. J. Sport Manag. 2019, in press. [CrossRef]

6. McCullough, B.P.; Orr, M.; Kellison, T. Sport ecology: Conceptualizing an emerging subdiscipline within sport management. J. Sport Manag. 2020, in press. [CrossRef]

7. Orr, M. On the potential impacts of climate change on baseball and cross-country skiing. Manag. Sport Leis. 2020, 25, 307-320. [CrossRef]

8. Orr, M.; Inoue, Y. Sport versus climate: Introducing the climate vulnerability of sport organizations framework. Sport Manag. Rev. 2019, 22, 452-463. [CrossRef]

9. Collins, A.; Munday, M.; Roberts, A. Environmental consequences of tourism consumption at major events: An analysis of the UK stages of the 2007 Tour de France. J. Travel Res. 2012, 51, 577-590. [CrossRef] 
10. Kellison, T.B.; Hong, S. The adoption and diffusion of pro-environmental stadium design. Eur. Sport Manag. Q. 2015, 15, 249-269. [CrossRef]

11. Trotta, G. Factors affecting energy-saving behaviors and energy efficiency investments in British households. Energ. Policy 2018, 114, 529-539. [CrossRef]

12. Breuer, C.; Feiler, S. Sports Clubs in Germany: Organisations and Internal Stakeholders; Sport Development Report for Germany 2017/18 Part 1; Federal Institute of Sports Science: Bonn, Germany, 2020.

13. Breuer, C.; Wicker, P.; Swierzy, P. Angemessene Mitgliedschaftsbeiträge in den Fußball und Leichtathletikvereinen des WFLV; [Appropriate Membership Fees in Football and Athletics Clubs]; GSU Cologne: Cologne, Germany, 2016.

14. Kiefer, S. Are riding club members willing to pay or work for overall quality improvement? Manag. Sport Leis. 2015, 20, 100-116. [CrossRef]

15. Swierzy, P.; Wicker, P.; Breuer, C. Willingness-to-Pay for Memberships in Nonprofit Sports Clubs: The Role of Organizational Capacity. Int. J. Sport Financ. 2018, 13, 261-278.

16. Wicker, P. Willingness-to-pay in non-profit sports clubs. Int. J. Sport Finance 2011, 6, 155-169.

17. Orlowski, J.; Wicker, P. Monetary valuation of non-market goods and services: A review of conceptual approaches and empirical applications in sports. Eur. Sport Manag. Q. 2019, 19, 456-480. [CrossRef]

18. Bertram, C.; Rehdanz, K. On the environmental effectiveness of the EU Marine Strategy Framework Directive. Mar. Policy 2013, 38, 25-40. [CrossRef]

19. Marmolo, E. A constitutional theory of public goods. J. Econ. Behav. Organ. 1999, 38, 27-42. [CrossRef]

20. Cornes, R.; Sandler, T. The Theory of Externalities, Public Goods and Club Goods; Cambridge University Press: Cambridge, UK, 1986.

21. Buchanan, J.M. An economic theory of clubs. Economica 1965, 32, 1-14. [CrossRef]

22. Nagel, S. Goals of sports clubs. Eur. J. Sport Soc. 2008, 5, 121-141. [CrossRef]

23. Doherty, A.; Millar, P.; Misener, K. Return to community sport: Leaning on evidence in turbulent times. Manag. Sport Leis. 2020, in press. [CrossRef]

24. Orlowski, J.; Wicker, P. Willingness to pay in sports. In The SAGE Handbook of Sports Economics; Downward, P., Humphreys, B.R., Frick, B., Pawlowski, T., Ruseski, J.E., Soebbing, B.P., Eds.; Sage: Thousand Oaks, CA, USA, 2019; pp. 415-427.

25. Carson, R.T. Contingent valuation: A user's guide. Environ. Sci. Technol. 2000, 34, 1413-1418. [CrossRef]

26. Carson, R.T.; Flores, N.E.; Meade, N.F. Contingent valuation: Controversies and evidence. Environ. Resour. Econ. 2001, 19, 173-210. [CrossRef]

27. Whitehead, J.; Wicker, P. Valuing nonmarket benefits of participatory sport events using willingness to travel: Payment card versus random selection with mitigation of hypothetical bias. Int. J. Tour. Res. 2019, 21, 180-186. [CrossRef]

28. Carson, R.T.; Mitchell, R.C.; Hanemann, M.; Kopp, R.J.; Presser, S.; Ruud, P.A. Contingent valuation and lost passive use: Damages from the Exxon Valdez oil spill. Environ. Res. Econ. 2003, 25, 257-286. [CrossRef]

29. Schuhmann, P.W.; Skeete, R.; Waite, R.; Lorde, T.; Bangwayo-Skeete, P.; Oxenford, H.A.; Spencer, F. Visitors' willingness to pay marine conservation fees in Barbados. Tour. Manag. 2019, 71, 315-326. [CrossRef]

30. Han, F.; Yang, Z.; Wang, H.; Xu, X. Estimating willingness to pay for environment conservation: A contingent valuation study of Kanas Nature Reserve, Xinjiang, China. Environ. Monit. Assess. 2011, 180, 451-459. [CrossRef] [PubMed]

31. Boyer, T.; Polasky, S. Valuing urban wetlands: A review of non-market valuation studies. Wetlands 2004, 24, 744-755. [CrossRef]

32. Ardeshiri, A.; Swait, J.; Heagney, E.C.; Kovac, M. Willingness-to-pay for coastline protection in New South Wales: Beach preservation management and decision making. Ocean. Coast. Manag. 2019, 178, 104805. [CrossRef]

33. Kalfas, D.G.; Zagkas, D.T.; Dragozi, E.I.; Zagkas, T.D. Estimating value of the ecosystem services in the urban and peri-urban green of a town Florina-Greece, using the CVM. Int. J. Sustain. Dev. World Ecol. 2020, 27, 310-321. [CrossRef]

34. Israel, D.; Levinson, A. Willingness to pay for environmental quality: Testable empirical implications of the growth and environment literature. BE J. Econ. Anal. Policy 2004, 3, 1-31. [CrossRef]

35. Ercolano, S.; Gaeta, G.L.; Romano, O. Environmental tax reform and individual preferences: An empirical analysis on European micro data. J. Behav. Exp. Econ. 2014, 51, 1-11. [CrossRef]

36. Huhtala, A. What price recreation in Finland? A contingent valuation study of non-market benefits of outdoor recreation areas. J. Leis. Res. 2004, 36, 23-44. [CrossRef]

37. Cicatiello, L.; Ercolano, S.; Gaeta, G.L.; Pinto, M. Willingness to pay for environmental protection and the importance of pollutant industries in the regional economy. Evidence from Italy. Ecol. Econ. 2020, 177, 106774. [CrossRef]

38. Witzke, H.P.; Urfei, G. Willingness to pay for environmental protection in Germany: Coping with the regional dimension. Reg. Stud. 2001, 35, 207-214. [CrossRef]

39. Tully, S.M.; Winter, R.S. The role of the beneficiary in willingness to pay for socially responsible products: A meta-analysis. $J$. Retail. 2014, 90, 255-274. [CrossRef]

40. Triantafyllidis, S.; Kaplanidou, K. Marathon Runners: A Fertile Market for "Green" Donations? J. Glob. Sport Manag. 2019, in press. [CrossRef]

41. Triantafyllidis, S.; Kaplanidou, K. Olympus Mountain Marathon and Participants Willingness to Pay for $\mathrm{CO}_{2}$ Offsetting: The Mediation Effect of Pro-Environmental Consciousness. In Proceedings of the 2018 NASSM Conference, Halifax, NS, Canada, 5-9 June 2018; pp. 43-44. 
42. Greenhalgh, G.; Drayer, J. An Assessment of Fans' Willingness to Pay for Team's Environmental Sustainability Initiatives. Sport Mark. Q. 2020, 29, 121-133.

43. Huth, C.; Kurscheidt, M. Membership versus green fee pricing for golf courses: The impact of market and golf club determinants. Eur. Sport Manag. Q. 2019, 19, 331-352. [CrossRef]

44. Diekmann, A.; Preisendörfer, P. Green and greenback. The behavioral effects of environmental attitudes in low-cost and high-cost situations. Ration. Soc. 2003, 15, 441-472. [CrossRef]

45. Ajzen, I. The theory of planned behavior. Organ. Behav. Hum. Decis. Process. 1991, 50, 179-211. [CrossRef]

46. Thormann, T.F.; Wicker, P. Determinants of pro-environmental behavior among voluntary sport club members. Ger. J. Exer. Sport Res. 2021, 51, 29-39. [CrossRef]

47. Kim, H.Y.; Chung, J.E. Consumer purchase intention for organic personal care products. J. Consum. Mark. 2011, $28,40-47$.

48. Wang, J.; Wang, S.; Wang, Y.; Li, J.; Zhao, D. Extending the theory of planned behavior to understand consumers' intentions to visit green hotels in the Chinese context. Int. J. Contemp. Hosp. Manag. 2018, 30, 2810-2825. [CrossRef]

49. Casper, J.M.; Pfahl, M.E.; McCullough, B. Intercollegiate sport and the environment: Examining fan engagement based on athletics department sustainability efforts. J. Issues Intercoll. Athl. 2014, 7, 65-91.

50. Kollmuss, A.; Agyeman, J. Mind the gap: Why do people act environmentally and what are the barriers to pro-environmental behavior? Environ. Educ. Res. 2002, 8, 239-260. [CrossRef]

51. Laroche, M.; Bergeron, J.; Barbaro-Forleo, G. Targeting consumers who are willing to pay more for environmentally friendly products. J. Consum. Mark. 2001, 18, 503-520. [CrossRef]

52. Franzen, A.; Meyer, R. Environmental attitudes in cross-national perspective: A multilevel analysis of the ISSP 1993 and 2000. Eur. Sociol. Rev. 2010, 26, 219-234. [CrossRef]

53. McCullough, B.P.; Pfahl, M.E.; Nguyen, S.N. The green waves of environmental sustainability in sport. Sport Soc. 2016, 19, 1040-1065. [CrossRef]

54. Veronesi, M.; Chawla, F.; Maurer, M.; Lienert, J. Climate change and the willingness to pay to reduce ecological and health risks from wastewater flooding in urban centers and the environment. Ecol. Econ. 2014, 98, 1-10. [CrossRef]

55. Preisendörfer, P. Umwelteinstellungen und Umweltverhalten in Deutschland [Environmental Attitudes and Pro-Environmental Behaviour in Germany]; Leske and Budrich: Leverkusen, Germany, 1999.

56. OECD. Measuring Well-Being and Progress. Available online: https://www.oecd.org/sdd/OECD-Better-Life-Initiative.pdf (accessed on 26 January 2021).

57. Lane, T. How does happiness relate to economic behavior? A review of the literature. J. Behav. Exp. Econ. 2017, 68, 62-78. [CrossRef]

58. Wicker, P.; Frick, B. Sustainable financing of elite athlete development: An empirical analysis of winter sports in Austria. Sustainability 2020, 12, 9664. [CrossRef]

59. Drouvelis, M.; Grosskopf, B. The effects of induced emotions on pro-social behaviour. J. Pub. Econ. 2016, 134, 1-8. [CrossRef]

60. Brown, K.W.; Kasser, T. Are psychological and ecological well-being compatible? The role of values, mindfulness, and lifestyle. Soc. Ind. Res. 2005, 74, 349-368. [CrossRef]

61. Sulemana, I. Are happier people more willing to make income sacrifices to protect the environment? Soc. Ind. Res. 2016, 127, 447-467. [CrossRef]

62. Frick, B.; Wicker, P. The monetary value of having a first division Bundesliga team to local residents. Schmalenbach Bus. Rev. 2018, 70, 63-103. [CrossRef]

63. Orlowski, J.; Wicker, P. The monetary value of voluntary coaching: An output-based approach. Int. J. Sport Financ. 2016, 11, 310-326.

64. Wicker, P. The carbon footprint of active sport participants. Sport Manag. Rev. 2019, 22, 513-526. [CrossRef]

65. Johnson, B.K.; Mondello, M.J.; Whitehead, J.C. Contingent valuation of sports: Temporal embedding and ordering effects. J. Sports Econ. 2006, 7, 267-288. [CrossRef]

66. Wicker, P.; Whitehead, J.C.; Johnson, B.K.; Mason, D.S. Willingness-to-pay for sporting success of Football Bundesliga teams. Contemp. Econ. Policy 2016, 34, 446-462. [CrossRef]

67. Wicker, P. The carbon footprint of active sport tourists: An empirical analysis of skiers and boarders. J. Sport Tour. 2018, 22, 151-171. [CrossRef]

68. Hair, J.F.; Black, W.C.; Babin, B.J.; Anderson, R.E. Multivariate Data Analysis, 7th ed.; Prentice Hall: Upper Saddle River, NJ, USA, 2010.

69. WHO. WHO-Five Well-Being Index. 1998. Available online: https://www.psykiatri-regionh.dk/who-5/who-5-questionnaires/ Pages/default.aspx (accessed on 27 January 2021).

70. Topp, C.W.; Østergaard, S.D.; Søndergaard, S.; Bech, P. The WHO-5 Well-Being Index: A systematic review of the literature. Psychother. Psychosom. 2015, 84, 167-176. [CrossRef]

71. Longhi, S. Individual Pro-Environmental Behaviour in the Household Context; ISER Working Paper Series; Institute for Social and Economic Research (ISER): Colchester, UK, 2013.

72. Castellanos, P.; Garcia, J.; Sanchez, J.M. The Willingness to Pay to Keep a Football Club in a City: How Important are the Methodological Issues? J. Sports Econ. 2011, 12, 464-486. [CrossRef]

73. Wooldridge, J.M. Introductory Econometrics: A Modern Approach; Thomson South-Western: Cincinnati, OH, USA, 2006. 
74. Bakkenbüll, L.; Dilger, A. Zahlungsbereitschaften für deutsche Erfolge bei den Olympischen Winterspielen 2014 in Sotschi. Ger. J. Exerc. Sport Res. 2017, 47, 360-370. [CrossRef]

75. Bakkenbüll, L.; Dilger, A. The willingness to pay for a German win of the 2014 FIFA World Cup in Brazil. Manag. Sport Leis. 2018, 23, 174-188. [CrossRef]

76. Wicker, P.; Kiefer, S.; Dilger, A. The value of sporting success to Germans: Comparing the 2012 UEFA Championships with the 2012 Olympics. J. Bus. Econ. 2015, 85, 897-919. [CrossRef]

77. Federal Statistical Office. Statistisches Jahrbuch Deutschland und Internationales 2019; [Annual Statistics Book Germany and International 2019]; Federal Statistical Office: Wiesbaden, Germany, 2019.

78. Tan, H.B.; Forgas, J.P. When happiness makes us selfish, but sadness makes us fair: Affective influences on interpersonal strategies in the dictator game. J. Exp. Soc. Psychol. 2010, 46, 571-576. [CrossRef]

79. Wicker, P.; Whitehead, J.C.; Mason, D.S.; Johnson, B.K. Public support for hosting the Olympic Summer Games in Germany: The CVM approach. Urban. Stud. 2017, 54, 3597-3614. [CrossRef]

80. DOSB. Bestandserhebung 2018 [Annual Statistics 2018]. Available online: https://cdn.dosb.de/user_upload/www.dosb.de/ uber_uns/Bestandserhebung/BE-Heft_2018.pdf (accessed on 27 January 2021). 